\title{
生物多様性に関する国際的枠組及
}

\section{Wanted: an IPCC for biodiversity}

2010 年 6 月 3 日号 Vol. 465 (525)

生物多様性の問題に関しても、独立した国際的な科学委員会を設立すべきである。

これによって、緊急性の高いテーマに関する研究活動を調整し、研究内容を社会に紹介する役割を果たせるだろう。

エコノミストNicholas Stern の主導に よって作成され、2006 年に発表された 気候変動の経済学に関する報告書は、長 期的な気候リスクに対応する必要性を、 世界の人々に喚起する警告となった。そ れもあって、この 10 月に発表予定の「生 態系と生物多様性の経済学」研究の最終 報告書は、「自然に関する Stern 報告書」 と管脍されている。当然、生物多様性損 失による大きな代償を明らかにするとと もに、生態系の破壊や生態系による恩恵 の慗失を明示した厳しい内容の報告書に なるとみられる。この生態系と生物多様 性の経済学に関する研究は、2007 年に ポツダム (ドイッ) で開催された主要 8 か国（G8）と新興 5 か国の環境担当大 臣会合の成果の 1 つだ。この研究の組 織者は、その成果を通して、政策立案者 の姿勢を正したいと期待している。

現在、気候変動に関する政府間パネル （IPCC）を連想させる組織を設立し、生 物多様性の変化を科学的に精査し、その 影響の予測をめざす動きが進行してい る。2010年 6 月 7 日〜 11 日、菳山(韓国) で、世界各国の代表が、「生物多様性お よび生態系サービスに関する政府間科学 政策プラットフォーム (IPBES)」とい う長ったらしい名前の付いた組織の設立 について議論し、詳細はともかく、その 設立に関しては合意をみた。

ところで、生物多様性という問題に対 処するうえで、IPCC モデルは適切なの だろうか。気候は全地球的問題であるの に対し、生物多様性の変化は、もっと地 域的な問題だ。IPBES 推進派もこの点 は認めており、IPBES は当初から、地
球規模だけでなく地域規模での評価にも 取り組むことになっている。気候変動に よって生じる極めて複雑な課題は、政策 立案者や一般市民にとって、「地球上の 気温がどこまで上昇するのか」といった 単一の指標に突きつめることができた。 しかし、生物多様性の場合、同様の重要 な単一の指標が存在しないのだ。

こうした違いはあるものの、気候変動 と生物多様性損失には、1 つの重要な共 通属性がある。ともに、経済的に重要な 実在の現象だということだ。ところが、 このことを無視してしまう人が少なくな い。IPCC の報告書によって、気候変動 の問題を無視することがかなり難しく なった。もし IPBES が、生物多様性と 生態系の変化についても同じ状況を生み 出すことができるなら、約 1200 万ドル （約 10 億円）と提案されている年間予 算は十分に価值あるものといえよう。

最近の問題に対応して改善を図るなら ば、IPCC は今後も国際レベルにおける 独立的科学評価の「究極のお手本」であ り続けるだろう。IPCC の報告書は、正 式な政府間プロセスの成果なのである。 IPBES の代表者は、このような特徵を 再現して IPBES を強力な組織とするよ う、最善を尽くすべきだ。

生物多様性を左右する全当事者と確実 に対話できるようにするため、IPBES は、 生物多様性条約だけでなく、その他の生物 多様性に関する条約、国連の諸機関、国 際環境非政府組織、国際的な科学機関や 民間部門とも正式な関係を構築すべきだ。

これまでのところ、IPBES は、国連 環境計画（UNEP）の支持を得ている。
国連環境計画は、世界気象機関 (WMO) とともにIPCC を監督している。また、 IPBES が環境官庁以外の部門から意見 や情報を得るために、さらに支援者の輪 を広げるべきだ。例えば、国連食糧農業 機関（FAO）が IPBES の運営に助力す れば、農業、漁業関係者のような食糧生 産の利害関係者が IPBES の結論を支持 する可能性が高くなるだろう。

生物多様性科学に関する標準や基盤 （インフラ）の整備は大いに必要とされ ており、IPBES はそれを重点的に進め ていくはずだ。スタンフォード大学（米 国カリフォルニア州パロアルト）の生態 学者で、IPBES 推進派の中心人物であ る Harold Mooney は、IPBES は世界的 変化の予測モデルの改良と標準化に力 を貸すべきだと主張している。そして、 IPBES の予算の一部は、当然のことなが ら開発途上国における科学研究能力の構 築に費やされていくことは間違いない。

さらに、IPBES は、地球観測グルー プ生物多様性観測ネットワーク (GEO BON）と強力な結びつきをもつように なることも間違いない。GEO BON は、 100 以上の政府機関とその他の団体が連 携している組織で、これらの機関や団体 は、既に生物多様性のデー夕と解析結果 を共有している。

GEO BON から質の高いデータを受 け、IPBESの活動によって調整された 研究を実施することで、生物多様性の科 学は発展すると考元られる。IPBES に よる定期的な評価は、地球上の生物相の 繁栄にも役立つことだろう。

(翻訳 : 菊川要) 